P. A. \& Korecka ja T. I., 1962: Ekologo-fiziologičeskije osobennosti krovi zemleroek i krotov. Tr. Inst. Morfol. Živ. im. A. N. Severcova, 41: 129-136. M e 11 a n b y K., 1971: The Mole. William Collins Sons \& Co Ltd: 1-159. Toronto. M or ris P., 1966: The mole as a surface dweller. J. Zool. (Lond.), 149: 46-49. O l s z e w s k i J. L. \& Skoczen S., 1965: The airing of burrows of the mole, Talpa europaea. Acta theriol., 10: 181-193. Quilli a m T. A., 1966: The mole's sensory apparatus. J. Zool. (Lond.), 149: 76-88. Quilli a m T. A., Clarke J. A. \& S a ls bury A. J., 1971: The ecological significance of certain new haematological findings in the mole and hedgehog. Comp. Biochem. Physiol., 40A: $89-102$. S c h a e f e r V. H., 1978: Aspects of habitat selection in the coast mole (Scapanus orarius True) in British Columbia. Simon Fraser University Ph. D. Thesis. 205 pp. S o u t h e r n H. N., 1954: Tawny owls and their prey. Ibis, 96: $384-410$.

Accepted, October 10, 1978.

\title{
Vocalization of the Shrews Suncus etruscus and Crocidura russula
} during Normothermia and Torpor

Głosy ryjówek: Suncus etruscus i Crocidura russula, przy normotermii i odrętwieniu

Rainer HUTTERER, Peter VOGEL, Henry FREY \& Michel GENOUD

\begin{abstract}
Hutterer R., Vogel P., Frey H. \& Genoud M., 1979: Vocalization of the shrews Suncus etruscus and Crocidura russula during normothermia and torpor. Acta theriol. 24, 21: 271-276 [With 1 Table \& 2 Figs.].

The vocalization of the shrews Suncus etruscus and Crocidura russula during normothermia and torpor is investigated. While frequency and call duration are independent of body temperature, the tremolo structure shows a spreading correlated with falling body temperature. The particular calls emitted during torpor are defence calls, modified by merely physiological factors. Their main function might be of intraspecific nature.
\end{abstract}

[Zool. Forschungsinst. u. Museum A. Koenig, D 5300 Bonn (RH) and Institut de zoologie et d'écologie animale, $\mathrm{CH} 1005$ Lausanne (PV, HF, MG)].

\section{INTRODUCTION}

Torpor in shrews was first demonstrated for Suncus etruscus (V o g e I, 1974) and since then observed in several species of Crocidurinae (N ag e 1, 1977; F r e y \& V o g e 1, 1979). There is also some evidence for the occurrence of torpor in three species of Soricinae (W olf, 1954; Lind s te d t, 1977; N e w m a n \& R u d d, 1978).

During torpor shrews stay immobile in the nest. When disturbed, they utter harsh shrieking calls ( $\mathrm{V}$ o g e l, 1974). This behaviour is the same in all shrew species in which torpor has been observed. The shrieking calls are clearly distinct from the vocal repertoire of normothermic animals. It is therefore of a certain interest to study these calls, especially the effect of body temperature on the form and frequency 
of the calls. The results may also give us an idea of the function of the calls.

\section{MATERIALS AND METHODS}

Studies were made with the shrews Suncus etruscus (S a vi, 1822) (mean body weight in captivity: 2.5 grams) and Crocidura russula (H e r mann, 1780) (mean body weight in middle Europe: 12 grams). The Etruscan shrews were taken from a laboratory colony established with animals from southern France; the common white-toothed shrews were caught in the surroundings of Lausanne.

Miost of the experimental animals were kept in a climate chamber $\left(14^{\circ} \mathrm{C}\right)$ during September 1977. During the experimental period the animals were under food shortage (Frey \& Vogel, 1979). Sound recordings were made between 8 and 9 a.m. in each case. For that purpose the shrews were removed from their nests, and recordings of vocalization and rectal temperature ( $\mathrm{Tr}$ ) were made simultaneously. The results of pilot recordings on two Etruscan shrews during November 1976 at Bonn are also included. During these recordings no measurements of $\operatorname{Tr}$ were made, that is why the body temperatures were calculated by means of comparable recordings afterwards. Evaluation was made from 6 recordings of $S$. etruscus and 7 recordings of $C$. russula at different body temperatures (Table 1).

In Lausanne we used a tape recorder Uher Report 4200 and a microphone Beyer Dynamic M88N, in Bonn an Uher Report 4000 and a Sennheiser MD44IN directional microphone. Registration speed was $19 \mathrm{~cm}$ per second, and registration distance 5 to $10 \mathrm{~cm}$. Sonagrams were made by use of a Kay Electric Vibralyser $7030 \mathrm{~A}$. The analysis of 124 calls includes the call duration, the number of frequency peaks of a single call, and the mean frequency of the most blackish drawing in the sonagram, i.e. the frequency with the maximum sound pressure.

\section{RESULTS}

The shrieking sounds of torpid shrews are often accompanied by jerky movements of the extremities. The readiness of the Etruscan shrews to utter sounds takes as long as they are unable to flee. After some minutes, when they are awake, they will immediately hide away. In comparison with that Crocidura russula calls awake as well, and in this species normothermic animals reply to any disturbance with loud defence calls. Apparently both species show a different species-specific behaviour.

To the human ear the calls of torpid shrews sound high-pitched compared with those of awake animals. In fact the frequency is nearly the same in awake and torpid shrews (Fig. 1); the calls of torpid shrews only lack the low frequencies, while the range from 14 to $18 \mathrm{kHz}$ is amplified. It can be seen from Table 1 that there is a considerable variation of the frequency in the Etruscan shrew, but there is no significant relation to the Tr. The frequency is rather likely to depend on the excitement level, for the Etruscan shrews show a tendency to higher and brighter calls in the case of a longer disturbance and with increasing duration of the call series. The calls of the common whitetoothed shrews, however, are more constant as a rule. The mean fre quency is $11.4 \mathrm{kHz}$ independent of the condition of the shrews. The mean frequency of the calls of the Etruscan shrews is $16.4 \mathrm{kHz}$, this is about $5 \mathrm{kHz}$ more than in the common white-toothed shrew.

The calls of both shrews show a tremolo-structure. While there is no appreciable effect of the $\operatorname{Tr}$ on the frequency, the calls of torpid shrews 
are characterized by a clear change in its rhythm (Fig. 1). It is therefore necessary to analyze the call duration as well as the number of frequency peaks in a single call. The call duration and the number of

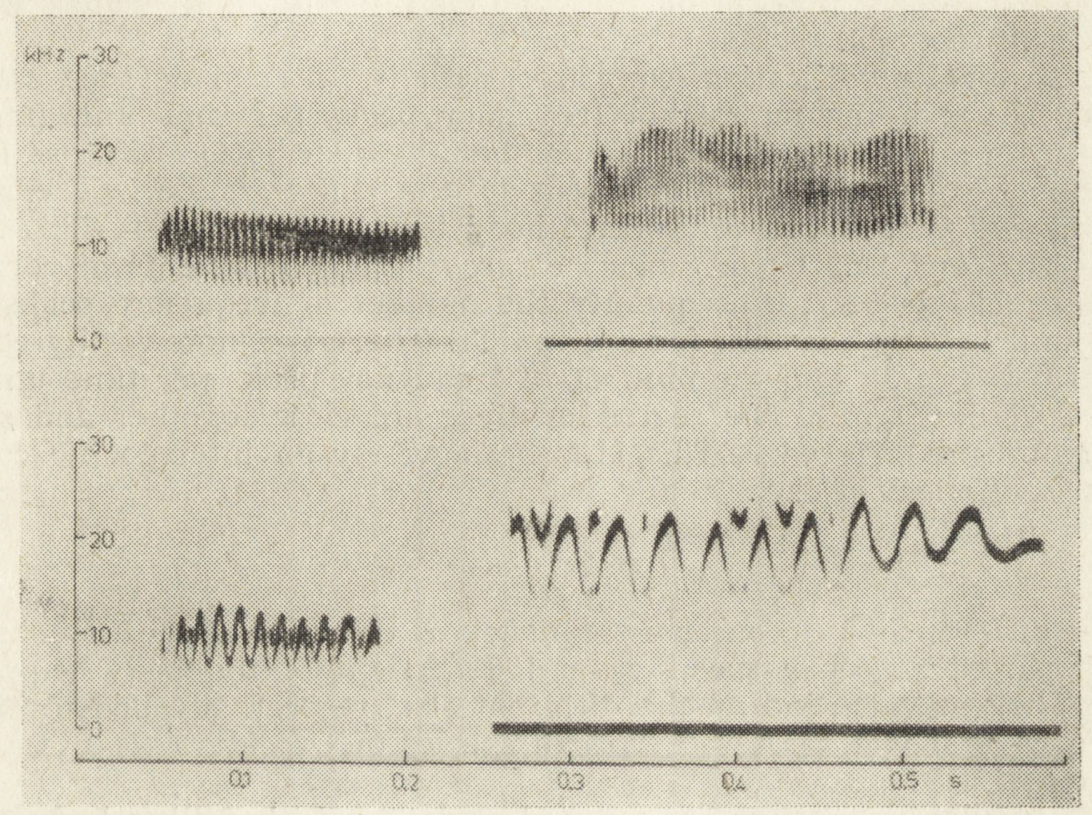

Fig. 1. Defence calls of Crocidura russula (on the left) and Suncus etruscus (on the right) during normothermia (upper row) and torpor (below).

Table 1

Characteristics of the calls.

\begin{tabular}{|c|c|c|c|c|c|c|c|}
\hline $\begin{array}{c}\text { Trial, } \\
\text { No }\end{array}$ & $\begin{array}{l}\text { Rectal } \\
\text { temp. } \\
\mathrm{Tr},{ }^{\circ} \mathrm{C}\end{array}$ & $\begin{array}{l}\text { Tor- } \\
\text { por }\end{array}$ & $\begin{array}{l}\text { Amplified } \\
\text { frequen- } \\
\text { cies }{ }^{1} \\
\text { kHz }\end{array}$ & $\begin{array}{l}\text { Number of } \\
\text { frequency } \\
\text { peaks }^{1}, \mathrm{~F}\end{array}$ & $\begin{array}{c}\text { Call } \\
\text { duration }{ }^{1} \\
\text { msec }\end{array}$ & $\begin{array}{c}\text { Modulation } \\
\text { rate }{ }^{1}, \\
\text { F/sec }\end{array}$ & $\begin{array}{l}\text { Number } \\
\text { of calls } \\
\text { analyzed }\end{array}$ \\
\hline
\end{tabular}

\begin{tabular}{rrrrrrrr}
\multicolumn{7}{c}{ Suncus etruscus } \\
1 & ca. $16.0^{2}$ & + & 16.8 & $10.1 \pm 1.8$ & $282.7 \pm 51.8$ & $35.7 \pm 8.7$ & 15 \\
2 & 16.2 & + & 14.9 & $8.7 \pm 1.8$ & $237.6 \pm 62.1$ & $36.6 \pm 4.8$ & 10 \\
3 & 18.4 & + & 18.2 & $12.1 \pm 2.6$ & $234.8 \pm 45.5$ & $51.5 \pm 3.3$ & 10 \\
4 & 23.0 & + & 14.8 & $13.1 \pm 2.6$ & $156.9 \pm 29.7$ & $83.5 \pm 5.9$ & 7 \\
5 & 24.5 & + & 17.3 & $12.8 \pm 3.5$ & $153.2 \pm 42.9$ & $83.6 \pm 3.0$ & 5 \\
6 & ca. $36.9^{2}$ & - & 16.4 & $24.3 \pm 13.6$ & $121.1 \pm 59.8$ & $200.7 \pm 31.5$ & 15 \\
& & \multicolumn{7}{c}{ Crocidura } & russula \\
1 & 23.7 & + & 10.8 & $6.8 \pm 1.8$ & $92.6 \pm 24.8$ & $73.4 \pm 8.5$ & 10 \\
2 & 25.2 & + & 11.5 & $7.6 \pm 3.4$ & $86.4 \pm 33.0$ & $88.0 \pm 9.3$ & 10 \\
3 & 28.4 & + & 12.2 & $14.7 \pm 5.4$ & $117.0 \pm 37.6$ & $125.6 \pm 8.2$ & 10 \\
4 & 33.6 & - & 11.1 & $15.4 \pm 12.4$ & $103.4 \pm 76.0$ & $148.9 \pm 19.3$ & 10 \\
5 & 33.8 & - & 11.0 & $10.4 \pm 3.5$ & $80.2 \pm 25.3$ & $129.7 \pm 15.2$ & 10 \\
6 & 34.6 & - & 11.6 & $9.9 \pm 4.6$ & $71.5 \pm 27.5$ & $138.5 \pm 16.7$ & 8 \\
7 & 36.3 & - & 11.8 & $18.5 \pm 10.7$ & $108.5 \pm 59.8$ & $170.5 \pm 9.3$ & 4 \\
\hline
\end{tabular}

1 Mean, or mean \pm standard deviation.

$2 \operatorname{Tr}$ calculated by means of comparable recordings. 
frequency peaks too show a great variation. While in Suncus etruscus the call duration decreases with rising $\mathrm{Tr}$, there is no such significant correlation in Crocidura russula (Table 1). The call duration may depend on the excitement level or on the stimulus intensity, both factors which are hard to control.

The critical modification, compared with the normal defence call, is the decrease of the number of frequency peaks per time unit (modulation rate in Table 1). To check whether the distribution of those modulations is regular and independent of the call duration, we computed the regression lines for several body temperatures $(16.0-16.2 ; 18.4$; $23.0-24.5$; and $26.9^{\circ} \mathrm{C}$ ) in Suncus etruscus. The coefficients of correlation are 0.94 to 0.97 ; consequently the number of frequency peaks per time unit is very constant for a given $\mathrm{Tr}$. There is a noteworthy correlation between $\operatorname{Tr}$ and the number of frequency peaks per time unit in both species (Fig. 2). The regression lines are close together and show no significant difference. This is also shown by an interspecific correlation coefficient of 0.98 .

\section{DISCUSSION}

The differences in the mean frequency of the calls of the two shrews are apparently species-specific and independent of the body temperature. They may depend on the different size, respectively body weight, as we have shown for seven African species of Crocidura ( $\mathrm{H} u$ t t e r e $r$ \& Vog e l, 1977).

The regular variation of the sound structure with falling body temperature shown in this paper (Fig. 1 and 2) was not known in a mammal

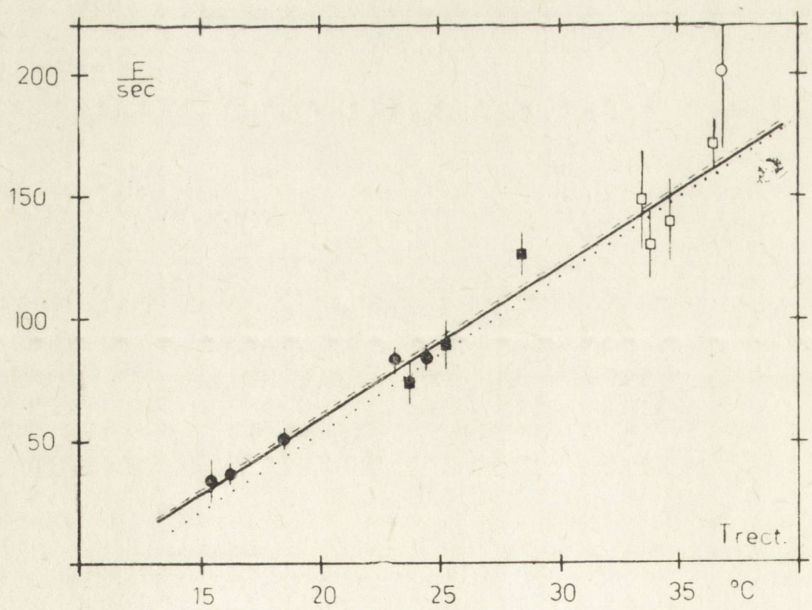

Fig. 2. The relation between body temperature $(\mathrm{Tr})$ and modulation rate $(\mathrm{F} / \mathrm{sec})$ of the calls in Suncus etruscus and Crocidura russula. The two experiments for which $\mathrm{Tr}$ was estimated afterwards are plotted in the diagram but were not used for the calculation of the regression lines. Explanation of symbols: Suncus etruscus normothermic, torpid; Crocidura russula $\square$ normothermic, torpid; interspecific regression line, $r=0.98 ;-\ldots-S$. etruscus, regression line, $r=0.99$; C. russula, regression line, $r=0.98$. 
before. Comparative relations are known in more detail in poikilothermic animals: in the amphibian Hyla arborea for instance, the call duration decreases with rising ambient temperature, while the number of pulses per time unit increases ( $\mathrm{S} c \mathrm{~h} n \mathrm{e} i \mathrm{~d}$ e $\mathrm{r}, 1977$ ). M a n z (1975) determined the fusion frequencies at which the muscles of the larynx of tree frogs go into tetanus. His results show a positive correlation between the temperature and the fusion frequency of the musculus dilatator laryngis. His results, if transferable to mammals, could easily explain our findings with shrews.

The calls of normothermic shrews are typical defence calls. They easily insert into the regression line (Fig. 2). It is clear from this that the vocalizations of torpid animals are extended defence calls, modified by the particular physiological condition. This interpretation is supported by the fact that the shrews utter these calls when disturbed. In awake animals defence calls are mainly caused by conspecifics; hence we suppose that the calls of a torpid shrew are an intraspecific signal of the animal that is unable to flee during deep torpor.

Similar calls have been observed in several Palaearctic hibernators, for instance in bats ( $\mathrm{E}$ is e $\mathrm{ntra} u \mathrm{t}, 1937$ ), in dormice ( $\mathrm{E}$ is e $\mathrm{ntraut}$, 1929; Zippelius \& Goethe, 1951; Koenig, 1960), Sicista betulina ( $\mathrm{P}$ a g a s t, 1950) and Cricetus cricetus ( $\mathrm{S} \mathrm{u} \mathrm{l} \mathrm{z} \mathrm{e} \mathrm{r,} \mathrm{1774).} \mathrm{Unfortuna-}$ tely no comprehensive analysis of those calls is available. In all the cases mentioned above the animals had been disturbed during torpor. Experiments to verify our hypothesis might therefore be of general interest.

Acknowledgements: We wish to express our thanks to Adelheid Geraets (Bonn), who helped with the sound recordings, and to Dr. W. Deutsch (Vienna), Prof. Dr. G. Ungeheuer, Dr. Stock (Bonn), and Prof. Dr Heike (Cologne), who allowed us to use sonagraphs. Charles Klaver (Amsterdam) kindly corrected the English version of the manuscript.

\section{REFERENCES}

E is entraut M., 1929: Beobachtungen über den Winterschlaf der Haselmaus (Muscardinus avellanarius L). Z. Säugetierkunde, 4, 213--239. E is e n tra u t M., 1937: Die deutschen Fledermäuse. Ein biologische Studie. Monogr. d. Wildsäugetiere II, 184 p., Leipzig. Fre y H. \& V o g e 1 P., 1979: Etude de la torpeur chez Suncus etruscus (Savi, 1822) (Soricidae, Insectivora) en captivité. Revue suisse Zool., 86: 23-36. Hutterer R. \& Vogel P., 1977: Abwehrlaute afrikanischer Spitzmäuse der Gattung Crocidura Wagler, 1832 und ihre systematische Bedeutung. Bonn. zool. Beitr., 28, 218-227. Ko enig L., 1960: Das Aktionssystem des Siebenschläfers (Glis glis L.). Z. Tierpsychol., 17, 427-505. L ind s te d t S. L., 1977: Physiological ecology of the smallest desert mammal, Notiosorex crawfordi. Thesis, Univ. Arizona, Univ. Microfilms, Ann Arbor, Michigan. M a n z R., 1975: Die Fusionsfrequenzen der Kehlkopfmuskeln und eines Beinmuskels in Abhängigkeit von der Temperatur bei europäischen Froschlurchen (Anura). Zool. Jb. Physiol., 79. 221-245. N a gel A., 1977: Torpor in the European white-toothed shrews. Experientia, 33, 1455-1456. N e w m a n J. R. \& $\mathrm{R}$ udd R. L., 1978: Observations of torpor-like behavior in the shrew Sorex sinuosus. Acta theriol., 23, 436-438. P ag a s t F., 1950: Zur Kenntnis der Gattung Sicista Gray. Zool. Jb. Syst. Ókol. Geogr. Tiere, 79, 87-92. Schneider H., 1977: Acoustic behavior and physiology of vocalization in the European tree frog, Hyla arborea (L.). [In: »The reproductive biology of amphibians «, Taylor D. H. \& Guttman S. I. eds.]. Plenum Publ. Corporation: 295-335. Sulz e r F. G. (1774, ed. by H. Petzsch, 1949): Versuch einer Naturgeschichte des Hamsters. Hannover \& Berlin-Zehlendorf, 200 p. + XVI. V og el P., 
1974: Kälteresistenz und reversible Hypothermie der Etruskerspitzmaus (Suncus etruscus, Soricidae, Insectivora). Z. Säugetierkunde, 39, 78-88. W o lf W., 1954: Spitzmäuse in Zwergmausnestern. Säugetierkundl, Mitt., 2: 33-34. Z i p pelius H.-M. \& G o e the F., 1951: Ethologische Beobachtungen an Haselmäusen (Muscardinus a. avellanarius L.). Z. Tierpsychol., 8: 348-367.

Accepted, January 4, 1979. 